\title{
ASSESSMENT OF WATER QUALITY STATUS IN THE IMPACT AREA OF THE "PIŠKORNICA" LANDFILL
}

\author{
Nenad Mikulić ${ }^{1,2^{*}}$, Roko Andričević ${ }^{3}$, Hrvoje Gotovac ${ }^{3}$, Matea Kalčiček ${ }^{1}$, Bojana Nardi $^{1}$ \\ ${ }^{1}$ Eko Invest, d.o.o., Draškovićeva 50, 10000 Zagreb \\ ${ }^{2}$ Polytechnic of Zagreb, Avenija Većeslava Holjevca 15, 10010 Zagreb \\ ${ }^{3}$ Faculty of Civil Engineering, Architecture and Geodesy in Split, Ulica Matice hrvatske 15, 21000 \\ Split \\ * E-mail of corresponding author: nenad.mikulic@ekoinvest.hr
}

\begin{abstract}
Disposal of household and industrial waste at the Piškornica site began in 1982 on what was then an unmanaged landfill cell, which allowed contamination to pass into underground layers. Landfill rehabilitation was conducted between 2005 and 2013 and conformed to the environmental protection conditions and measures that were prescribed by an EIA procedure, but rehabilitation still has not been fully completed. An environmental permit was issued for rehabilitation of the landfill. The decision and environmental permit prescribed groundwater quality monitoring. Prior to these documents, five piezometers were placed into operation in 1991. The objective of this paper is to determine the potential differences in ground and surface water quality that may have resulted from landfill operations, effectiveness of the rehabilitation efforts, and the potential risk of contamination of the Ivanščak water well. The results of the research were subjected to statistical analyses (e.g., T-test and ANOVA). Based on the regional flow model, a numerical groundwater flow model and contamination transport model were created, which provided scenarios for the potential spread of pollution from the Piškornica landfill while considering different water well operation regimes. It was concluded that a) even though rehabilitation has not been completed, the groundwater quality status improved and b) none of the analysed real flow scenarios generated redirection of streamline patterns towards the Ivanščak water well. Considering future development and likely increase of the Ivanščak well capacity, the expansion of monitoring was proposed for additional measuring locations.
\end{abstract}

Keywords: monitoring, landfill impact, landfill rehabilitation, contamination transport, contamination risk

\begin{tabular}{c}
\hline Received: $29.4 .2020 . /$ Accepted: 28.8 .2020$. \\
Published online: 7.12.2020. \\
\hline \\
Original scientific paper \\
https://doi.org/10.37023/ee.7.2.8
\end{tabular}

\section{INTRODUCTION}

The Piškornica landfill is located in the area of Koprivnički Ivanec municipality, which is north of the city of Koprivnica and is approximately $1 \mathrm{~km}$ from the nearest settlement of Pustakovec, approximately $2 \mathrm{~km}$ from the Koprivnički Ivanec settlement and approximately $8 \mathrm{~km}$ from the centre of the City of Koprivnica. The landfill location was included in the spatial plan of Koprivnica-Križevci County. At the current location, the disposal of industrial and municipal waste has occurred since 1982, while prior to rehabilitation, disposal had been carried out in an unsanitary manner in which an impermeable bottom, as a solution for drainage of seeping water from the treatment plant, had not been constructed. In 1991, the first preliminary design for landfill rehabilitation was developed and was planned to be included for continuation of operations as a sanitary landfill. Approximately ten years later (2001), a new "Preliminary Design of a Category I Landfill at the Piškornica - Koprivnica Site" was developed and in March 2001, an Environmental Impact Study was adopted (IPZ Uniprojekt MCF 2001). The location and building permits for the rehabilitation and final landscaping of the Piškornica landfill were issued in 2004. Landfill rehabilitation began in 2005 and has been implemented in several phases over several years. As of today, rehabilitation of cells 1, 2 and 3 at the Piškornica landfill has been carried out and since 2018, waste has been disposed of in cell 4 in a sanitary manner. The current status is that approximately $100,000 \mathrm{~m}^{3}$ of waste has been left unrehabilitated outside the landfill boundary and is located outside the present fence and is south of the landfill body (Figure 1). 


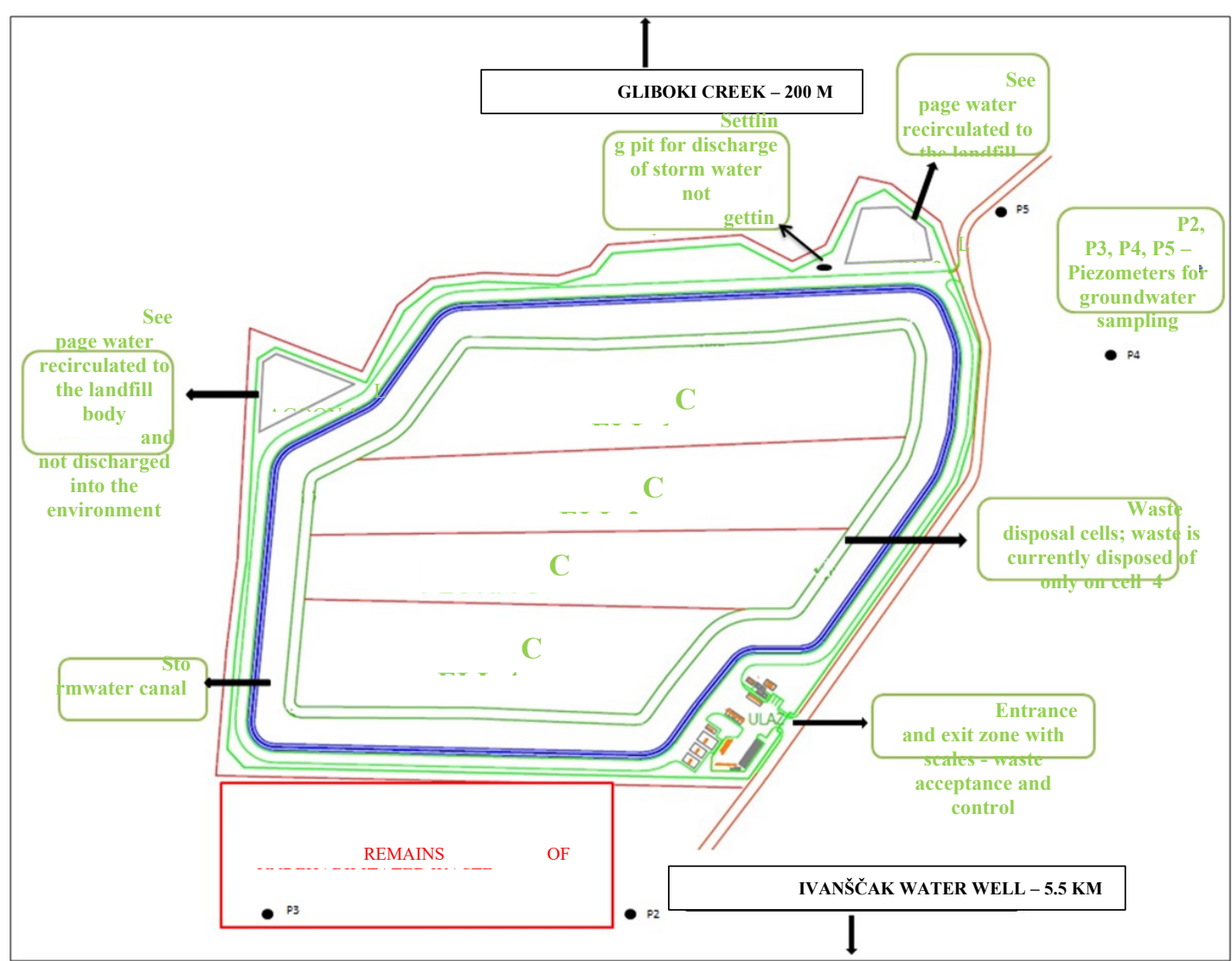

Figure 1. Layout of the Piškornica landfill with the unrehabilitated cell

To monitor groundwater quality in the immediate vicinity of the landfill, five piezometers (e.g., P1-P5) were installed in 1991. Today, based on the environmental permit (Okolišna dozvola 2016), the Piškornica landfill is obligated to conduct measurements of basic water quality indicators in groundwater at piezometers P2, P3, P4 and P5 and in the surface water of the Gliboki water body at locations G1 (Pustakovec Bridge) and G2 (Đelekovec Bridge) with a minimum sampling frequency of four times per year during landfill operations by applying analytical measuring methods (Figure 2).

Testing of groundwater and surface water quality status in recent years, including 2018, has been conducted by the accredited laboratory at the Public Health Institute of Koprivnica-Križevci County in cooperation with the Public Health Institute of Primorje-Gorski Kotar County and the Andrija Stampar Teaching Institute of Public Health in Zagreb.

It is presumed that all measurements were performed in the referenced laboratory and that all parameters were investigated with the same methodology.

The Gliboki watercourse is a torrential watercourse where flow amounts are significantly affected by precipitation. As we had no information regarding the water flows at the points where samples were taken, it was also presumed that sampling was performed at approximately equal flow rates. 


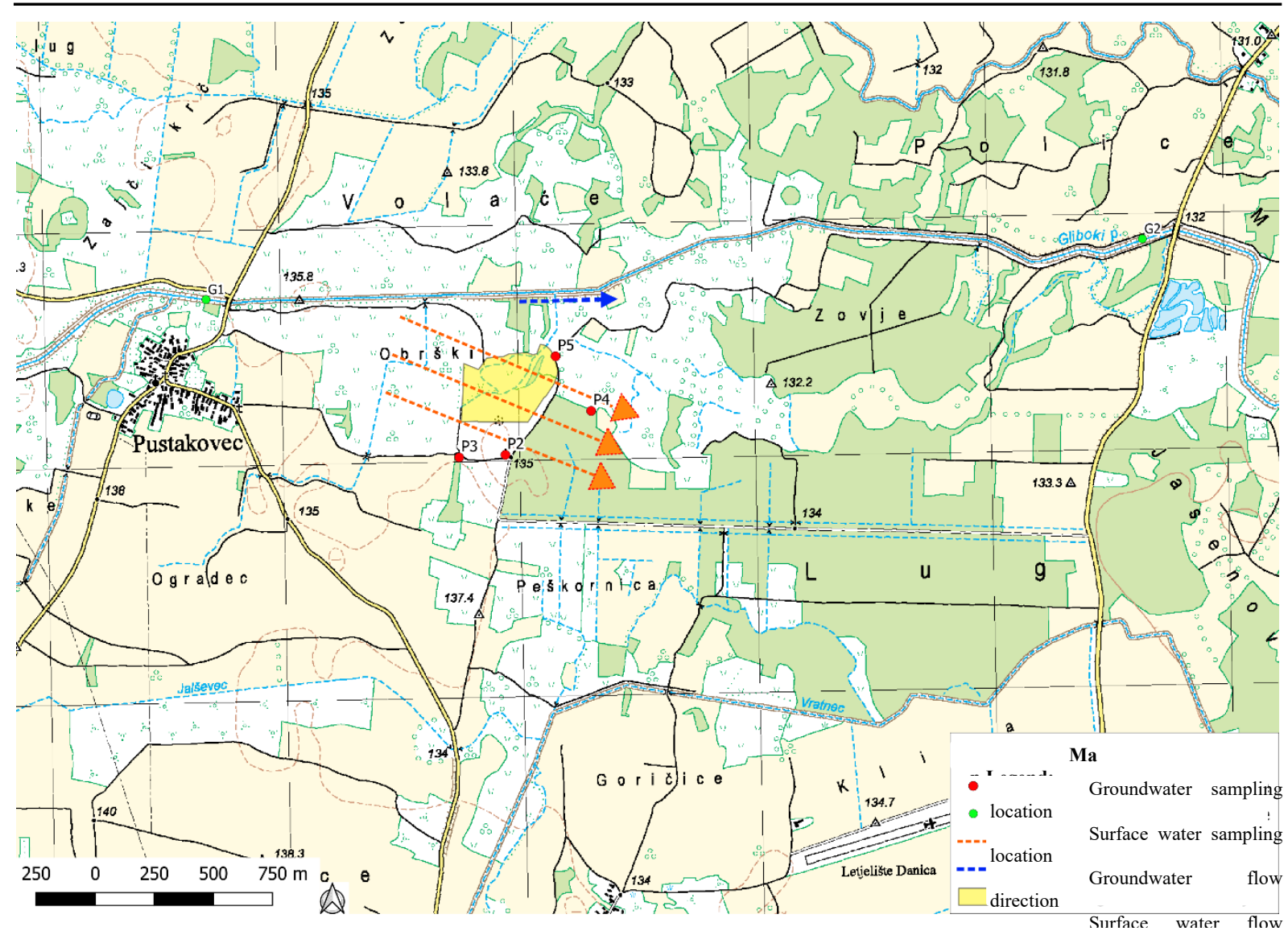

Figure 2. Piezometer locations and sampling points of the Gliboki water body (measuring profile G1 upstream) and measuring profile $G 2$ downstream from the landfill which are marked with the flow directions of groundwater and surface water in the area of the Piškornica landfill (Source: Ruk, D. et al. (2018))

\section{GROUNDWATER AND SURFACE WATER ANALYSIS}

Testing was conducted in the periods before and during rehabilitation until 2012 and after rehabilitation was carried out until year 2018. The rehabilitation period itself, which ran from 2005 to 2013, was considered as the pre-rehabilitation period (Mikulic, N. et al 2019).

The testing results of water samples from the piezometers (P2, P3, P4 and P5) were analysed and included determinations of electrical conductivity, COD, BOD and iron plus the testing results of surface water samples from the nearest water body, Gliboki, which is situated north of the Piškornica landfill. The Gliboki water body was sampled at two locations, namely, upstream of the landfill site at the Pustakovac Bridge (G1), which was used as a control sample, and downstream of the landfill itself, at the Đelekovac Bridge (G2), which is potentially affected by the landfill. For the Gliboki water body, the electrical conductivity, COD, BOD, copper and zinc values were analysed.

Heavy metals may be present in landfill leachates and their concentrations depend not only on waste compositions but also on the decomposition stage

Organic compounds in leachates create anaerobic conditions which release dissolved iron and manganese. We note that the alluvial aquifers of the River Drava are rich in iron and manganese salts. Because iron is present with naturally high concentrations in the underground waters of the observation area, it is difficult to assess iron impacts only by using its related concentrations (Elinder CG. 1986).

The analyses of heavy metal pollution origins in watercourses show that copper and zinc concentrations depend only partially on landfill emissions but are also influenced by untreated waste water emissions and agriculture along the watercourse

The parameters with the longest testing periods and those covering prior periods (during) and post rehabilitation, which were obtained both at the piezometers and at Gliboki Creek, were obtained for processing. Heavy metals that had the longest measurement times were selected for analysis of groundwater and surface water.

In addition, to identify possible differences in the quality of groundwater and surface water in the area of the Piškornica landfill as well as in the vicinity of the landfill site itself, at different stages of landfill operations (i.e., the pre- and post-rehabilitation periods until 2018), statistical analyses of selected datasets were carried out.

The starting point for analysis was the assumption that all testing was carried out in the same reference laboratory by using the same methodology for all analysed parameters. Groundwater flows were taken according to the flows used in the model and are presented later in this paper. 
Similar to surface water quality monitoring, for monitoring the water quality of the nearest surface water body, Gliboki, parameters with the longest testing history were selected which were electrical conductivity, COD, BOD5 and the heavy metals, copper and zinc.

The testing results of the following samples were statistically processed:

- Groundwater samples from piezometers at locations around the landfill (e.g., P2, P3, P4 and P5) were tested for the following water quality characteristics: COD, BOD, electrical conductivity and Fe.

- The surface waters of the Gliboki watercourse that were sampled upstream (G1 location) and downstream (G2 location) from the landfill were tested for the following water quality characteristics: $\mathrm{COD}, \mathrm{BOD}$, electrical conductivity, $\mathrm{Cu}$ and $\mathrm{Zn}$.

By applying appropriate statistical methods (e.g., T-test and variance analysis), the mean values of the testing results that were obtained before the completion of rehabilitation, i.e., until the end of 2012 (V1) were compared with the results obtained after completion of rehabilitation, i.e., from 2013 to 2018 (V2) for all observed quality characteristics and for all locations (e.g., P2, P3, P4, P5, G1 and G2).

Furthermore, the trends from sample testing were statistically processed and analysed for:

- $\quad$ Groundwater samples from the piezometers at locations around the landfill (e.g., P2, P3, P4 and P5) were tested for the following water quality characteristics: COD, BOD, electrical conductivity and $\mathrm{Fe}$

- Surface waters of the Gliboki watercourse that were sampled upstream (G1 location) and downstream (G2 location) from the landfill were tested for the following water quality characteristics: COD, $\mathrm{BOD}$, electrical conductivity, and $\mathrm{Cu}$ and $\mathrm{Zn}$

\section{DETAILS OF THE PROCESSING RESULTS OF DATA OBTAINED THROUGH MEASUREMENTS}

\section{a. Groundwater}

The COD groundwater trend is shown in Figure 3.

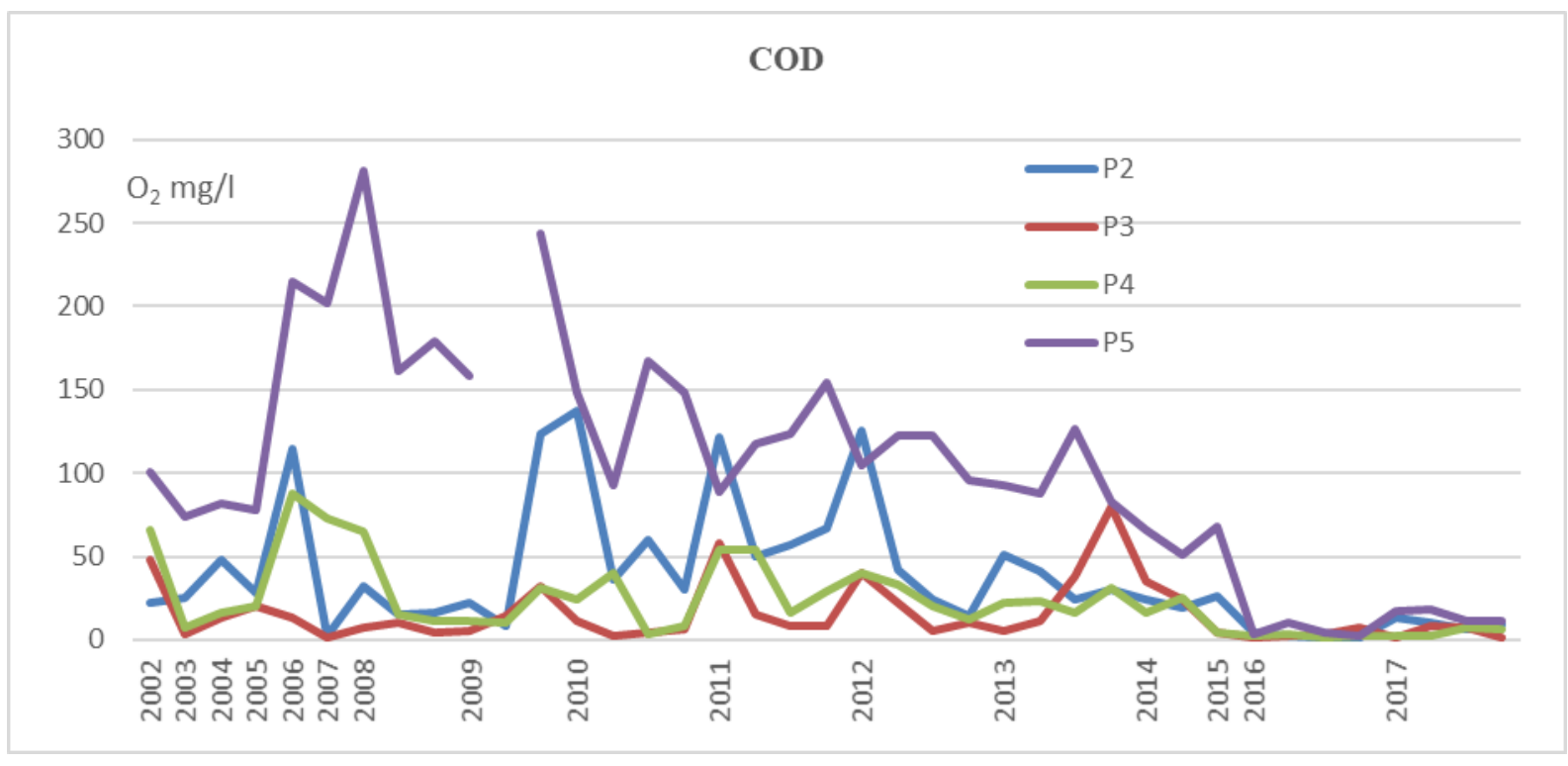

Figure 3. COD trends at the P2, P3, P4 i P5 piezometers in the period 2002-2018

The results show that a trend of decreasing COD was observed for all piezometers, especially after 2012, when landfill remediation was mostly completed. 


\section{b. Surface water}

COD trends in surface water are shown in Figure 4.



Figure 4. COD (KPK) in the surface water sampled upstream for profile G1 (m. Pustakovac) and downstream for profile $G 2$ ( $m$. Delekovac) from the landfill during the period from 2008 to 2018.

COD distribution trends do not lead to the conclusion that the Piškornica landfill has had a significant impact on the Gliboki watercourse.

\section{STATISTICAL ANALYSIS}

The aim of the statistical analysis and trend analysis was to assess, with reasonable certainty, the effectiveness of the Piškornica landfill rehabilitation, which was carried out from 2005 to 2012 in accordance with the terms of the referenced contract.

\section{a. Groundwater}

The results of t-tests related of the quality indicators (e.g., COD, BOD, conductivity and Fe) are shown in Table 1. By testing the differences in mean values of the results obtained from the P2 through P5 piezometers before (V1) and after (V2) landfill remediation, we can evaluate the impact of specific parameters on groundwater quality (Mendenhall W. 1986).

Table 1. Significance differences between variances before remediation (V1) and after remediation (V2) for the $\mathrm{P} 2$ to $\mathrm{P} 5$ piezometers ( $\mathrm{t}$-test, alpha level $95 \%$ ) and $\mathrm{O}=$ total number of individual observations)

\begin{tabular}{|c|c|c|c|c|c|}
\hline Attribute & Piezometer & $\begin{array}{c}\text { V1 } \\
\text { (before remed.) }\end{array}$ & $\begin{array}{c}\mathrm{V} 2 \\
\text { (after remed.) } \\
\end{array}$ & t-exspon. & Note \\
\hline \multirow{4}{*}{ COD } & $\mathrm{P} 2$ & $50,89(\mathrm{O}=24)$ & $17.47(\mathrm{~N}=15)$ & 3.56 & $\mathrm{~V} 1>\mathrm{V} 2$ \\
\hline & $\mathrm{P} 3$ & $15.15(\mathrm{O}=24)$ & $15.4(\mathrm{~N}=15)$ & 0.04 & $\mathrm{~V} 1=\mathrm{V} 2$ \\
\hline & $\mathrm{P} 4$ & $31.13(\mathrm{O}=24)$ & $11.05(\mathrm{~N}=15)$ & 3.65 & $\mathrm{~V} 1>\mathrm{V} 2$ \\
\hline & $\mathrm{P} 5$ & $141.69(\mathrm{O}=23)$ & $43.48(\mathrm{~N}=15)$ & 5.93 & $\mathrm{~V} 1>\mathrm{V} 2$ \\
\hline \multirow{4}{*}{ BOD } & $\mathrm{P} 2$ & $13.16(\mathrm{O}=24)$ & $5.64(\mathrm{~N}=15)$ & 2.44 & $\mathrm{~V} 1>\mathrm{V} 2$ \\
\hline & P3 & $3.88(\mathrm{O}=24)$ & $6.76(\mathrm{~N}=15)$ & 1.15 & $\mathrm{~V} 1=\mathrm{V} 2$ \\
\hline & $\mathrm{P} 4$ & $4.91(\mathrm{O}=24)$ & $2.96(\mathrm{~N}=15)$ & 1.47 & $\mathrm{~V} 1=\mathrm{V} 2$ \\
\hline & P5 & $28.67(\mathrm{O}=23)$ & $5.22(\mathrm{~N}=15)$ & 7.55 & $\mathrm{~V} 1>\mathrm{V} 2$ \\
\hline \multirow{4}{*}{ Conductivity } & $\mathrm{P} 2$ & $949(\mathrm{O}=27)$ & $923(\mathrm{~N}=12)$ & 0.15 & $\mathrm{~V} 1=\mathrm{V} 2$ \\
\hline & P3 & $515(\mathrm{O}=25)$ & $472(\mathrm{~N}=12)$ & 1.13 & $\mathrm{~V} 1=\mathrm{V} 2$ \\
\hline & $\mathrm{P} 4$ & $649(\mathrm{O}=26)$ & $682(\mathrm{~N}=12)$ & 0.24 & $\mathrm{~V} 1=\mathrm{V} 2$ \\
\hline & P5 & $2330(\mathrm{O}=27)$ & $1454(\mathrm{~N}=12)$ & 2.45 & $\mathrm{~V} 1>\mathrm{V} 2$ \\
\hline
\end{tabular}




\begin{tabular}{|c|c|c|c|c|c|}
\hline \multirow{4}{*}{ Fe } & $\mathrm{P} 2$ & $25191.2(\mathrm{O}=27)$ & $3548.5(\mathrm{~N}=12)$ & 1.96 & $\mathrm{~V} 1=\mathrm{V} 2$ \\
\cline { 2 - 6 } & $\mathrm{P} 3$ & $2993.3(\mathrm{O}=26)$ & $1579.2(\mathrm{~N}=12)$ & 1.995 & $\mathrm{~V} 1=\mathrm{V} 2$ \\
\cline { 2 - 6 } & $\mathrm{P} 4$ & $11676.6(\mathrm{O}=27)$ & $2682.8(\mathrm{~N}=12)$ & 2.02 & $\mathrm{~V} 1=\mathrm{V} 2$ \\
\cline { 2 - 6 } & $\mathrm{P} 5$ & $15292.7(\mathrm{O}=27)$ & $4354.3(\mathrm{~N}=12)$ & 1.77 & $\mathrm{~V} 1=\mathrm{V} 2$ \\
\hline
\end{tabular}

Regarding the iron content values, no significant differences were found at any of the piezometer locations (P2 to P5) between the results of testing that was performed before completion of rehabilitation (V1) and the results of testing for Fe contents that were obtained after rehabilitation was carried out (V2). In addition, there were no significant differences between the mean values of the testing results obtained from piezometer locations P2 through P4 when compared to the values at piezometer location P5. The high variance values suggest that there is a large scatter in individual Fe testing results from which the mean values were calculated.

The t-test results show a significant decrease in COD values from P2, P4 and P5 after rehabilitation. The findings from ANOVA further reveal the results of rehabilitation (Table 2).

Table 2. COD variance analysis for piezometers P2 through P5 before remediation.

\begin{tabular}{|c|c|c|c|c|c|c|}
\hline Group & Observation & Sum & Mean & Variance & & \\
\hline $\mathrm{P} 2$ & 24 & 1221,38 & 50.89 & 1751.0426 & & \\
\hline P3 & 24 & 363.55 & 15.15 & 222.45279 & & \\
\hline P4 & 24 & 747.15 & 31.13 & 560.82877 & & \\
\hline P5 & 23 & 3258.77 & 141.69 & 3004.9011 & & \\
\hline \multicolumn{7}{|l|}{ ANOVA } \\
\hline Source of var. & $S S$ & $d f$ & $M S$ & $F$ & $P$-value & $F$ critic \\
\hline Between groups & 223617.3 & 3 & 74539.1099 & 54.52739 & $2.9024 \mathrm{E}-20$ & 2.7047034 \\
\hline Within groups & 124397.3 & 91 & 1367.003088 & & & \\
\hline Total & 348014.6 & 94 & & & & \\
\hline
\end{tabular}

F $>$ Fcrit- differences are significant

Table 3. COD variance analysis for piezometers $\mathrm{P} 2$ through $\mathrm{P} 5$ after rehabilitation

\begin{tabular}{|c|c|c|c|c|c|c|}
\hline Group & Observation & Sum & Mean & Variance & & \\
\hline P2 & 15 & 262.12 & 17.47 & 228.69796 & & \\
\hline P3 & 15 & 231.02 & 15.4 & 461.80418 & & \\
\hline P4 & 15 & 165.76 & 11.05 & 102.61599 & & \\
\hline P5 & 15 & 652.18 & $\mathbf{4 3 . 4 7}$ & 1670.9321 & & \\
\hline ANOVA & & & & & & Frit. \\
\hline Source of var. & SS & $d f$ & $M S$ & & & \\
\hline Between groups & 9677.305 & 3 & 3225.768293 & 5.2365301 & 0.00294979 & 2.7694309 \\
\hline Within groups & 34496.7 & 56 & 616.0125538 & & & \\
\hline Total & 44174.01 & 59 & & & & \\
\hline
\end{tabular}

$\mathrm{F}>\mathrm{Fcrit}-$ differences are significant

Our conclusion, which is based on the statistical analysis performed, is that the Piškornica landfill resulted in significant reductions in COD, BOD and electrical conductivity values at the location of piezometer P5 and to lesser extents at locations P2 (for COD and BOD values) and P4 (for COD values). We conclude from the results that the COD and electrical conductivity values at the P5 location were significantly higher than those at other locations (e.g., P2 to P4) and note that the differences between measured values after landfill rehabilitation were smaller than the differences measured before rehabilitation. These results indicate the significant relationship between flow routes and piezometer locations. 


\section{b. Surface water}

The results of t-tests that were related to the quality indicators (e.g., COD, BOD, $\mathrm{Cu}$ and $\mathrm{ZN}$ ) were obtained by testing samples from Gliboki Creek before (V1) and after (V2) landfill remediation are shown in Table 4.

Table 4. Significances of differences between variances before remediation (V1) and after remediation (V2) for the G1 profile (upstream) and for the G2 profile (downstream) (t-test, alpha level 95\%)

\begin{tabular}{|c|c|c|c|c|c|}
\hline Attribute & Sampled & G1 & G2 & t-exp. & Note \\
\hline \multirow{3}{*}{$\mathrm{COD}$} & $\mathrm{V} 1$ (before rem.) $(\mathrm{O}=9)$ & 10.1 & 8.76 & 0.48 & $\mathrm{G} 1=\mathrm{G} 2$ \\
\cline { 2 - 6 } & $\mathrm{V} 2$ (after rem.) $(\mathrm{O}=13)$ & 5.97 & 5.37 & 0.65 & $\mathrm{G} 1=\mathrm{G} 2$ \\
\hline \multirow{3}{*}{$\mathrm{BOD}$} & $\mathrm{V} 1$ (before rem.) $(\mathrm{O}=9)$ & 3 & 3.33 & 0.68 & $\mathrm{G} 1=\mathrm{G} 2$ \\
\cline { 2 - 6 } & $\mathrm{V} 2$ (after rem.) $(\mathrm{O}=13)$ & 2.58 & 1.53 & 2.12 & $\mathrm{G} 1>\mathrm{G} 2$ \\
\hline \multirow{3}{*}{ conductivity } & V1 (before rem.) $(\mathrm{O}=9)$ & 420 & 466 & 1.37 & $\mathrm{G} 1=\mathrm{G} 2$ \\
\cline { 2 - 7 } & $\mathrm{V} 2$ (after rem.) $(\mathrm{O}=13)$ & 445 & 481 & 1.77 & $\mathrm{G} 1=\mathrm{G} 2$ \\
\hline \multirow{3}{*}{$\mathrm{Cu}$} & $\mathrm{V} 1$ (before rem.) $(\mathrm{O}=9)$ & 2.25 & 1.43 & 0.74 & $\mathrm{G} 1=\mathrm{G} 2$ \\
\cline { 2 - 7 } & $\mathrm{V} 2$ (after rem.) $(\mathrm{O}=13)$ & 7.74 & 7.63 & 0.03 & $\mathrm{G} 1=\mathrm{G} 2$ \\
\hline \multirow{2}{*}{$\mathrm{Zn}$} & $\mathrm{V} 1$ (before rem.) $(\mathrm{O}=9)$ & 15.26 & 14.65 & 0.08 & $\mathrm{G} 1=\mathrm{G} 2$ \\
\cline { 2 - 7 } & $\mathrm{V} 2$ (after rem.) $(\mathrm{O}=13)$ & 42.64 & 73.61 & 0.6 & $\mathrm{G} 1=\mathrm{G} 2$ \\
\hline
\end{tabular}

From the statistical analysis, we conclude that, for the selected attributes, no significant differences were found between the results obtained before rehabilitation and those obtained after rehabilitation of the Piškornica landfill.

There are two exceptions:

- $\quad$ For profile G2 (downstream) there was a significant BOD reduction after rehabilitation which should be investigated,

- After rehabilitation, $\mathrm{Cu}$ concentrations increased for both sampling profiles, i.e., both upstream and downstream from the landfill location.

Based on the results of statistical analysis of the measured values of the observed quality characteristics (e.g., $\mathrm{COD}, \mathrm{BOD}$, electrical conductivity), and $\mathrm{Cu}$ and $\mathrm{Zn}$, we conclude that the impact of the Piškornica landfill on the surface water quality of the Gliboki watercourse is not significant but note that the possible cause of increased $\mathrm{Cu}$ contents after rehabilitation in the studied area is from the impacts of agricultural activities on the testing results.

\section{REGIONAL FLOW MODEL IN THE PIŠKORNICA AREA}

Regional flow and transport modelling are standard tools for analysing water quality in landfill areas. Flow analysis is usually conducted by using finite element methods (e.g., Ackerer et al. 1999; Voss 1984; Holzbecher, 1998) while transport analysis is determined by a random walk Lagrangian approach (e.g., Rubin 2003; La Bolle et al. 1998; Park et al. 2008). To numerically model groundwaters flow and pollution transfer over a broad area around the Piškornica landfill (Duić \& Urumović 2007), the Fi programme was used (Gotovac 2002; Jović, 1993; Urumović 2003). This programme was written in the Fortran language and is used for numerical analysis of stationary seepage through a two-dimensional porous medium by using the finite element method.

Eight-node finite elements were used to discretize the geometry of the area. Hydraulic conductivity is represented as a full conductivity-tensor that is constant in the elements but is variable by area. This allows for observations of stationary flow through a heterogeneous aquifer (each element may have a different conductivity tensor). Essential or Dirichlet boundary conditions were defined as specified piezometric heights (potential). Pumping and recharge points are included as concentrated inflows into the network nodes, distributed load or production of the required field by area (constant within elements) as well as the fluxes at the edges of the elements, which were defined as one-dimensional elements and were separately set. Such fluxes represent natural or Neumann boundary conditions. The equation system was solved by a frontal procedure.

\subsection{Description of Boundary Conditions}

Figure 5 shows the boundaries of the regional flow model. To obtain a realistic flow state in the area around the Piškornica landfill, it was necessary to correctly set the boundary conditions. On the north side, Drava was the boundary that was used to determine the global regional flow in the model. Drava was defined as an impermeable boundary (streamline) so that the regional flow would run parallel to Drava, as was indicated by field measurements. For the eastern portion, a boundary with a Dirichlet boundary condition of $140 \mathrm{~m}$ was defined. On the western side, a boundary with a Dirichlet boundary condition of $120 \mathrm{~m}$ was defined. The south boundary was a defined as an impermeable boundary (respectively, streamline) that was roughly parallel to the Drava flow and 
the other side was at a sufficient distance from Piškornica and the water well to not affect the model results. Such definitions of boundary conditions agree with those of (Urumović et al. 1996).

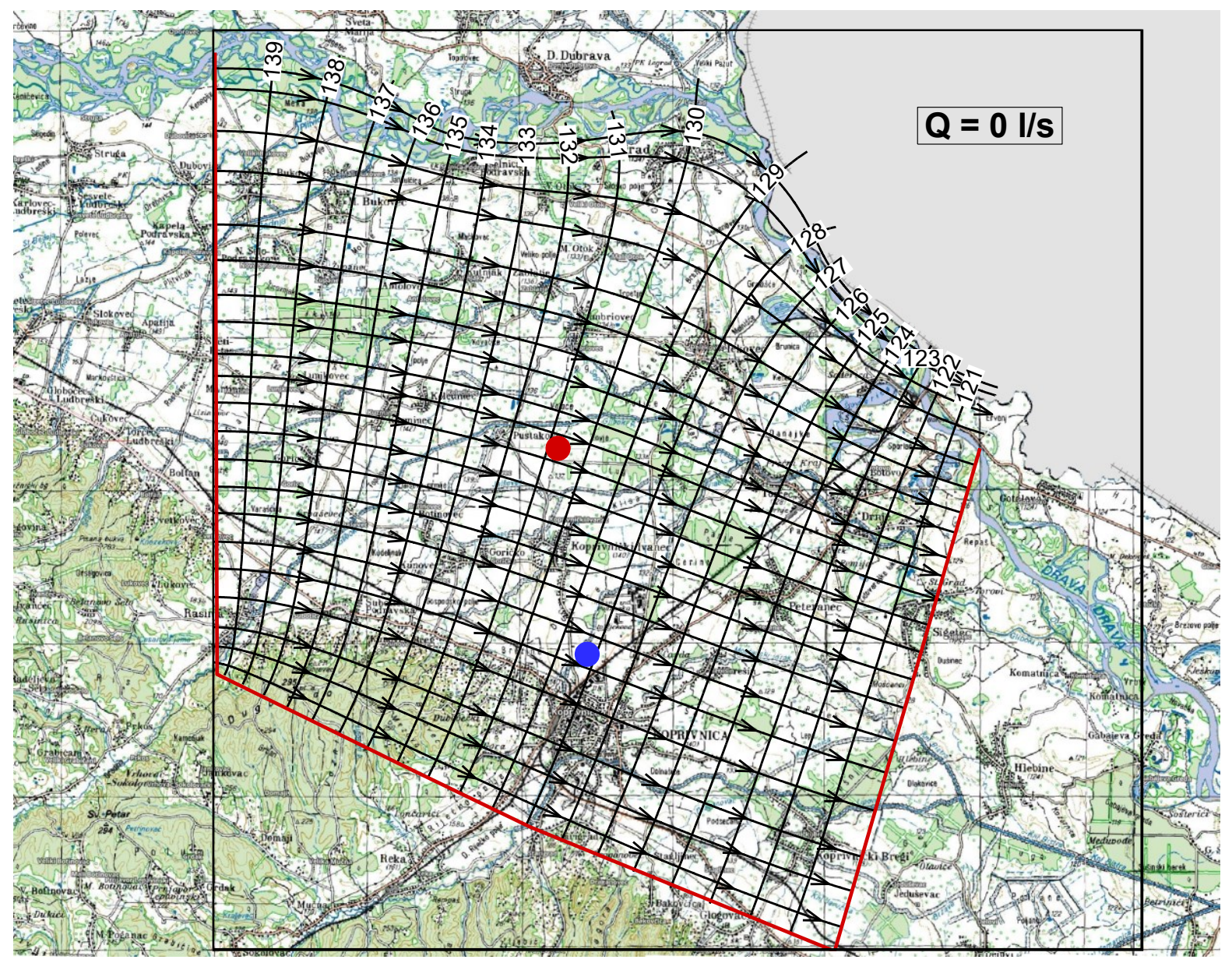

Figure 5. View of the regional flow model domain in the area of Piškornica (red circle - landfill, blue circleIvanščak water well, red lines - domain boundary)

\subsection{Ivanščak Water Well}

The Ivanščak water well (Figure 6) is located approximately $5.5 \mathrm{~km}$ from the landfill. Hydrogeological analysis of the water well was conducted in a study by Urumović et al. (1996). The water well had a significant impact on the hydrodynamic flow configuration in the observed domain. Significant over-pumping could cause a direct connection between the Piškornica landfill and the water well that supplies the city of Koprivnica. It should be noted that the landfill area does not fall into the I, II or IIIa water well protection zones. The water exploitation so far does not confirm any impacts by the landfill on the water quality in the water well. Considering that the water well is the most important water source in the observed domain and its impact on the results of the regional flow model, five basic flow scenarios, S1-S5, were defined and the velocity field was the main input variable for analysing conservative transport at the landfill that defines the advective transport component:

$\mathrm{S} 1-\mathrm{Q}=0(1 / \mathrm{s}) ;$ No pumping.

$\mathrm{S} 2-\mathrm{Q}=100(\mathrm{l} / \mathrm{s})$; Corresponds to the current average pumping.

$\mathrm{S} 3-\mathrm{Q}=200(\mathrm{l} / \mathrm{s})$; Corresponds to the current maximum pumping.

$\mathrm{S} 4-\mathrm{Q}=420(\mathrm{l} / \mathrm{s})$; Corresponds to the maximum pumping with respect to the current water well capacity. $\mathrm{S} 5-\mathrm{Q}=600(\mathrm{l} / \mathrm{s})$; Corresponds to the pumping level that would cause a direct hydrodynamic connection between the water well and the Piškornica landfill. 


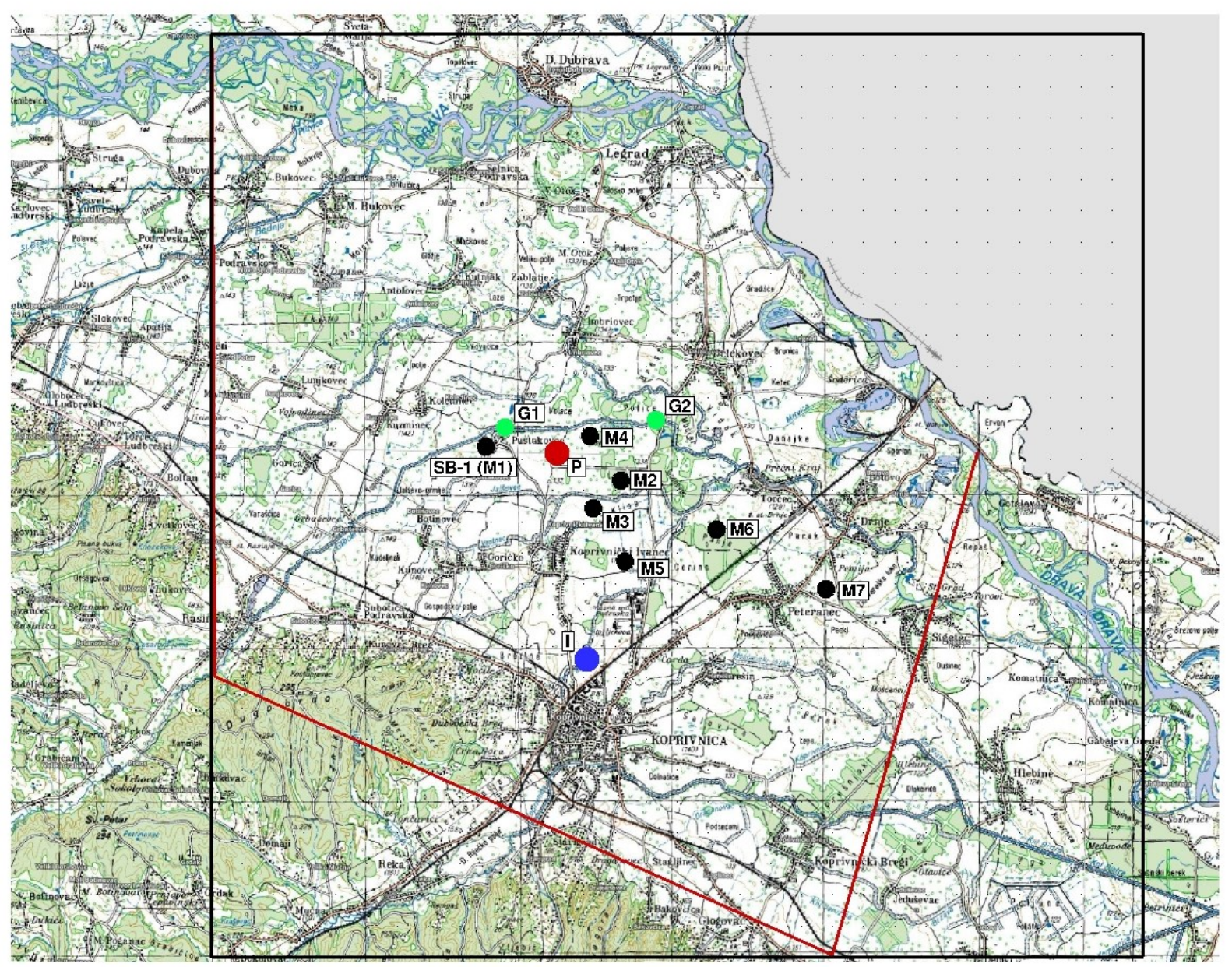

Figure 6. View of the observation points used in the transport analysis for the area of the Piškornica landfill (landfill-P, Ivanščak water well-I, Gliboki Creek-G1 and G2, and piezometers M1 to M7 that represent future monitoring).

Each flow scenario was defined by a different streaming image which implies different cloud expansion properties in the sense of their spatial and temporal movements as well as concentration magnitudes.

Figure 6 shows the observed area with ten observation points at which the pollution cloud movement was monitored and the possible effects on water bodies were analysed. The three primary observation points are the Piškornica landfill - P, Ivanščak water well - I and Gliboki Creek - G. The other observation points represent piezometers M1 to M7 which can be used for future monitoring. M1 is the piezometer located approximately 2 $\mathrm{km}$ from the landfill and is at the site where the deep well SB-1 is located. It was proposed that this well be used as M1 and would determine the flow conditions and water quality upstream from the landfill. The M2 piezometer is located approximately $1.75 \mathrm{~km}$ from the landfill and is on a stream that comes from the landfill and was used for pumping simulation S2 which corresponds to present day pumping conditions. The M3 piezometer is located approximately $1.75 \mathrm{~km}$ from the landfill and is located on a stream coming from the landfill and was used for pumping simulation S5, which is the case when a direct hydrodynamic connection between the landfill and the water well is established. M4 is located approximately $1.25 \mathrm{~km}$ from the landfill near Gliboki Creek. M4 can be compensated for by the measurements in Gliboki Creek and monitors the pollution cloud toward this water body. The M6 and M7 piezometers determine the movement of the pollution cloud from the main possible propagation direction along with M2. M6 is $4.87 \mathrm{~km}$ from the landfill and M7 is approximately $8.12 \mathrm{~km}$ from the landfill. M5, at a distance of $3.3 \mathrm{~km}$, was used determining the movement of the cloud from the landfill toward the Ivanščak water well along with M3. In this way, all three possible downstream directions of cloud propagation in space and time were monitored.

The basic input data were defined in the regional flow model, namely, the domain, edges, finite element network and velocity field for flow scenarios S1-S5. An effluent, which is a pollution cloud defined as a series of particles in the transport analysis, forms at the landfill. In this analysis, we observe the momentary injection of waste at the moment the landfill is opened when 2,000 particles are injected into the model (Figure 6 - shown in red circle - P). This is a simpler version while the other approach is to define a continuous pollution source (which in reality occurs at the landfill and requires introducing new particles at each temporal step. However, this simpler 
version shows all of the essential properties of conservative transport in terms of the spatial and temporal distributions of the pollution cloud. A realistic scenario would be much more important if reactive chemical transport were also considered.

\subsection{Explanation of Results Obtained Through Models}

Based on five flow scenarios, S1-S5, for different pumping amounts of the Ivanščak water well, the pollution cloud transport behaviours downstream from the Piškornica landfill were analysed. The pollution cloud propagation in space and time was analysed and the cloud was monitored at ten observation points. Thus, pollution was monitored at the upstream piezometer M1 and at the landfill body (point P) and also in three basic directions: 1) the direction of the main regional flow extending from the northwest to the southeast between Gliboki Creek and the Ivanščak water well (piezometers M2, M6 and M7); 2) the direction from the landfill to the Ivanščak water well (piezometers M3, M5 and I); and 3) the direction from the landfill to Gliboki Creek (piezometer M4 and existing measuring stations G1 and G2).

The results of the analysis show that, for the S1-S3 flow scenarios, there are no significant differences among the pollution transport results. The regional flow runs from the northwest to southeast. Advection causes the cloud to travel between Gliboki Creek and the water well but, however, is closer to the creek. There is no direct hydrodynamic connection between the landfill and water well or between the landfill and Gliboki Creek. Therefore, the field of streams from the landfill that defines the advection forces the pollution cloud to travel with its centre along the P-M2-M6-M7 route.

Due to pumping at $600 \mathrm{l} / \mathrm{s}$ at the Ivanščak water well, the streams rotate toward the water well so that a direct hydrodynamic connection is established between the landfill and water well. Therefore, the field of streams from the landfill that defines the advection forces the pollution cloud to travel directly towards the water well. Figure 7 shows that the maximum concentrations at the M2 piezometer ( $40 \%$ of the initial concentration) decrease compared to scenarios S1-S3 and significantly decrease at M6 $(0.7 \%)$ while the pollution cloud does not reach M7 (0\%). The concentration curves in the piezometers have shapes that are very similar to normal distributions where they reach a maximum at M2 in six years and at M6 in 12 years. All c-t curves have zero values until the first pollution particles reach their environment. Therefore, the first travel times of the pollution cloud are to M2 at approximately five years, to M6 at approximately 12 years, and to M7 at approximately 25 years. The c-t curves have non-zero values during the time period when the pollution cloud travels across their respective areas. After the cloud passes, the concentrations in the c-t transient curves are once again zero. This non-zero-time segment defines the variance of the c-t transient curve (the variance equals its sixth), which is approximately one year for piezometers M2 and M6.

The dimensions of the pollution cloud at the landfill were estimated as $0.5 * 0.5 \mathrm{~km}$. The pollution cloud is carried downstream by advection and dispersion increases and dilutes the cloud and after 15 years, divides the cloud into two parts such that one part moves towards the water well and the other part moves towards the Drava River.

Figure 8 shows the characteristics of pollution transport towards the Ivanščak water well. In this flow scenario, S5, the cloud directly reaches the water well. It takes 20 years for the cloud to reach the water well and, after 60 years, approximately $43 \%$ of the initial pollution mass has been incorporated into the affected drinking water. After 26 years, the maximum pollutant concentration at the landfill is $5.1 \%$. The two piezometers placed between the landfill and water well show that at M3, the maximum concentration is $7.5 \%$ and at M5, it is $5.7 \%$.

The remaining question is whether the pollution cloud threatens Gliboki Creek in scenario S5. Considering the direct connection between the landfill and water well, the regional flow is altered to a completely different direction, so at M4 and Gliboki Creek - G, the concentrations are zero which mean that there is no pollution and that Gliboki Creek is not in direct contact with the pollution cloud from the landfill. 


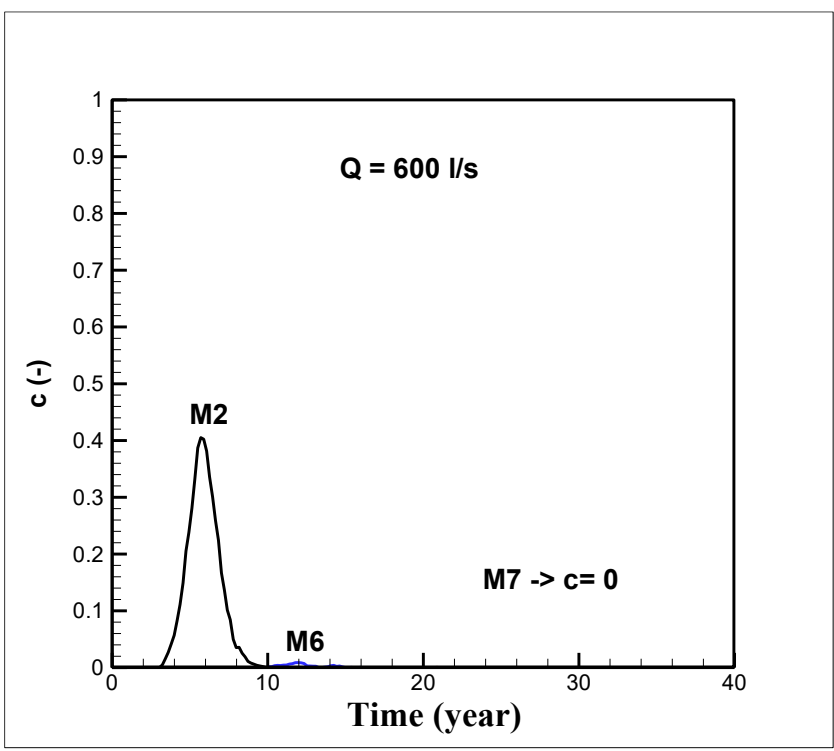

Figure 7. Representation of the dependence of non-dimensional concentrations and times for flow scenario S5 at observation points M2, M6 and M7

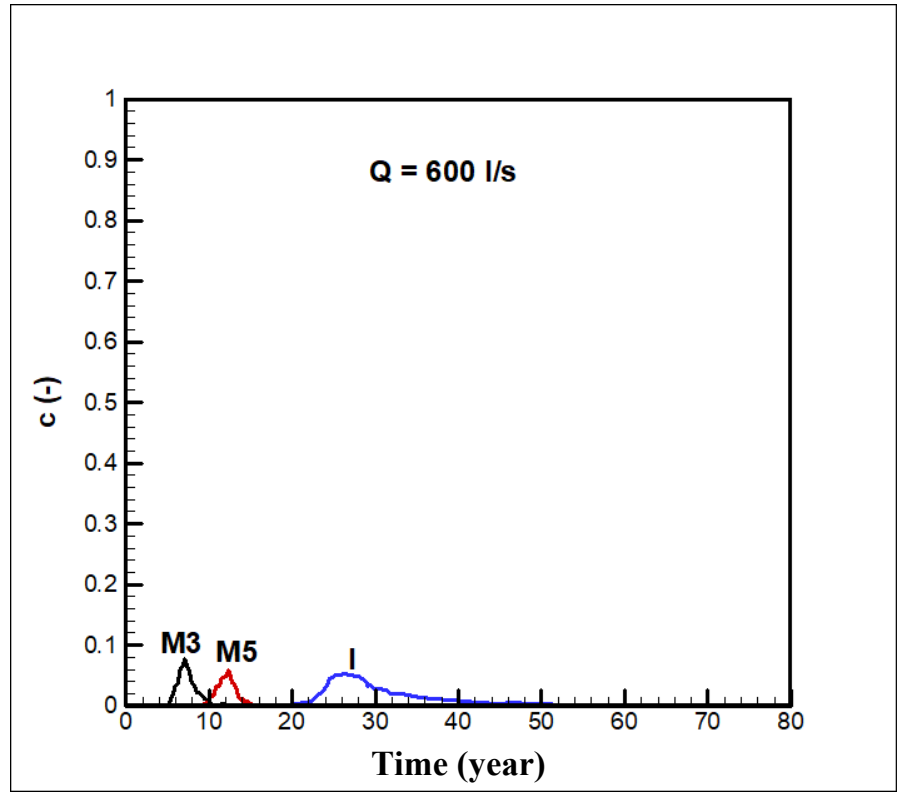

Figure 8. Representation of the dependence of non-dimensional concentrations and times for flow scenario S5 at observation point I - Ivanščak and piezometers M3 and M5

The results show that in all realistic scenarios of S1-S4 flows, there is no propagation of the pollution cloud into the water bodies of Gliboki creek and the Ivanščak water well. In the direction of regional flow (Figure 5) for flow scenario $\mathrm{S} 3$, it is evident that the maximum concentrations are at the M2 piezometer (59\% of the initial concentration) and decrease gradually at M6 (25\%) and M7 (16\%). The concentration curves for the piezometers exhibit shapes that are very similar to normal distributions for which they reach a peak at M2 in 7.5 years, at M6 in 19 years, and at M7 in 35 years. The first travel times of the pollution cloud are: to M2 at approximately three years, to M6 at approximately 13 years, and to M7 at approximately 26 years. The pollution cloud passes the farthest piezometer M7 after 35 years when it has dimensions of approximately $4 * 3 \mathrm{~km}$. Likewise, scenario S4 shows that even at the maximum water well capacity of $420 \mathrm{l} / \mathrm{s}$, pollution of the Ivanščak water well does not occur. Any increase in the pumping capacity in the future to approximately $600 \mathrm{l} / \mathrm{s}$ in flow scenario S5 would cause a direct hydrodynamic connection between the landfill and water well and drinking water pollution would occur after approximately twenty years from the cloud formation at the landfill if the landfill had not been fully rehabilitated. Finally, the ten observation points used in the pollution transport analysis will serve as a template for future monitoring. 


\section{CONCLUSION}

Based on the analysis of laboratory test results, we conclude that landfill rehabilitation resulted in a significant positive change in groundwater quality status in the landfill environment by examining the COD, BOD and electrical conductivity values while the testing results of $\mathrm{Fe}$ contents did not change significantly after landfill rehabilitation was carried out.

The greatest changes in the values of the observed water quality characteristics after rehabilitation were observed at location P5, which is situated near the northeastern part of the landfill while at the location of the P3 piezometer, which is situated near the southwestern part of the landfill, no significant changes in the values of water quality characteristics were observed after landfill rehabilitation.

Furthermore, the analysis showed that the impact of the Piškornica landfill on the surface water quality of the Gliboki watercourse is not significant.

The results of the analysis based on the model show that in all realistic flow scenarios S1-S4, there is no propagation of the pollution cloud into the water bodies of the Gliboki creek and the Ivanščak water well. Moreover scenario S4 shows that even at the maximum water well capacity of $420 \mathrm{l} / \mathrm{s}$, pollution of the Ivanščak water well does not occur. Any increase in the pumping capacity in the future to approximately $600 \mathrm{l} / \mathrm{s}$ in flow scenario S5 would cause a direct hydrodynamic connection between the landfill and water well and drinking water pollution would occur after approximately twenty years from initial cloud formation at the landfill if the landfill had not been fully rehabilitated. Finally, the ten observation points used in the pollution transport analysis will serve as a template for future monitoring.

\section{REFERENCES}

Ackerer P, Younes A, Mose R (1999) Modeling variable density flow and solute transport in porous medium: 1. Numerical model and verification. Transp Porous Media; 35 (3): 345-73

Duić Ž, Urumović K (2007) Utjecaj strukture legradskog praga na hidrogeološke značajke u području Koprivnice. Rudarsko-geološko- naftni zbornik, RGN, Zagreb

Elinder CG (1986) Handbook on the toxicology of metals. 2. ed., Elsevier Science Publishers, Amsterdam

Gotovac H (2002) Fi-program za analizu tečenja i pronosa u podzemlju, FCEA, Split.

Halamić J \& Miko S (2009) Geokemijski atlas Republike Hrvatske. Croatian Institute of Geology, Zagreb. Holzbecher E (1998) Modeling density-driven flow in porous media. Springer, Berlin

IPZ Uniprojekt MCF d.o.o. (2000) Studija o utjecaju na okoliš uređenja postojećeg odlagališta komunalnog otpada „Piškornica”; Zagreb

Jović V (1993) Uvod u inženjersko numeričko modeliranje. Aqarius, Split

La Bolle EM, Fogg GE, Tompson AFB (1996) Random-Walk Simulation of Transport in Heterogeneous Porous Media: Local Mass-Conservation Problem and Implementation Methods. Water Resources Research, 32 (3)

Mendenhall W, Sincich T (1988) Statistics for the Engineering and Computer Scinences. 2nd ed., San Francisco: Dellen Publ. Comp.

Mikulic N, Andricevic R, Gotovac H, Kalcicek M (2019) Studija ocjene stanja voda i tla na neposrednom utjecajnom području odlagališta otpada Piškornica, Piškorinca sanacijsko odlagalište d.o.o., Koprivnica.

Okolišna dozvola za odlagalište komunalnog optada Piškorinca, Ministarstvo zaštite okoliša i energetike, 2016, Zagreb.

Park C-H, Beyer C, Bauer C, Kolditz O (2008) A study of preferential flow in heterogeneous media using random walk particle tracking. Geosciences Journal 12(3):285-297. doi: 10.1007/s12303-008-0029-2

Ruk D, Nemcic-Jurec J, Horvat I, Martinaga N, Gres N (2018) Izvještaj radne skupine za odlagalište otpada Piškornica o monitoringu površinskih i podzemnih voda, Piškornica - sanacijsko odlagalište d.o.o., Koprivnica.

Urumović K, Hlevnjak B, Gold H (1996) Vodoopskrbni sustav Koprivnice. Hidrogeološka studija razvitka crpilišta Ivanščak, Rudarsko-geološko-naftni fakultet, Zagreb

Urumović K (2003) Fizikalne osnove dinamike podzemnih voda. Faculty of Mining, Geology and Petroleum Engineering, Zagreb University, Zagreb.

Voss CI (1984) A finite-element simulation model for saturated-unsaturated fluid-density-dependent groundwater flow with energy transport or chemically-reactive single-species solute transport, U.S. Geol. Surv. Water Resour. Invest., 409 